\title{
Differential T-Helper Cell Polarization after Allergen-Specific Stimulation of Autologous Dendritic Cells in Polysensitized Allergic Patients
}

\author{
Kazem Ashjaei ${ }^{a} \quad$ Merima Bublin $^{a} \quad$ Ursula Smole ${ }^{a}$ Nina Lengger ${ }^{a}$ \\ Christine Hafner $^{b}$ Heimo Breiteneder ${ }^{a}$ Stefan Wagner ${ }^{a}$ \\ Karin Hoffmann-Sommergruber ${ }^{\text {a }}$ \\ ${ }^{a}$ Department of Pathophysiology and Allergy Research, Medical University of Vienna, Vienna, and \\ ${ }^{b}$ Karl Landsteiner Institute of Dermatological Research, St. Poelten, Austria
}

\section{Key Words}

Monocyte-derived dendritic cells · Th1/Th2 cells · Phl p 5 .

Bet $\mathrm{v} 1 \cdot$ Allergy

\begin{abstract}
Background: Dendritic cells (DCs) play an important role in the induction and regulation of adaptive immune responses by polarizing T-helper (Th) cells. In allergic disease this response is dominated by Th2 cells. It is still unclear whether the activation of Th cells by DCs in atopic individuals is allergen specific. Methods: Monocyte-derived DCs (MoDCs) obtained from polysensitized patients were stimulated with purified Bet v 1, Phl p 5 and Act d 10, and the surface marker expression was analysed. Proliferation and cytokine profiles of autologous naïve CD4+ T cells co-cultured with allergenpulsed MoDCs were assessed. Results: The addition of either Bet $v 1$ or Phl p 5 did not further increase the expression of surface markers from matured MoDCs in all study groups. In co-cultures, autologous naïve CD4+ T cells proliferated when DCs obtained from individuals allergic to birch and grass pollen were stimulated with Bet $v 1$ and Phl p 5, respectively. In the co-culture supernatants, significantly increased levels of IL-5 and IL-13 were detected. This effect correlated with the sensitization background and was absent when applying an unspecific allergen, Act d 10. The levels of IL-10 in superna-
\end{abstract}

tants of MoDCs and the levels of IL-10 and IFN- $\gamma$ in supernatants of $T$ cells remained unchanged upon stimulation with allergens. Conclusions: In this study we observed that allergen-specific stimulation of MoDCs induces T-cell proliferation and upregulation of Th2-type cytokines. Interestingly, this Th2 polarization was only observed in cells stimulated with the allergen to which the patients were sensitized.

(c) 2015 S. Karger AG, Base

\section{Introduction}

Allergic diseases are recognized as a serious health problem affecting both industrialized and developing countries, and the prevalence of allergic diseases (e.g. allergic rhinoconjunctivitis, asthma and eczema) has increased rapidly [1].

Dendritic cells (DCs) are the most potent antigen-presenting cells of the innate immune system, with the potential to regulate adaptive immune responses, and play an important role in the allergic sensitization phase. They recognize, capture and present foreign antigens to $\mathrm{T}$ cells

This study is in memory of our esteemed colleague Stefan Wagner, who started this project. He passed away in December 2012.

\begin{tabular}{ll}
\hline KARGER 125:3 & $\begin{array}{l}\text { (2015 S. Karger AG, Basel } \\
1018-2438 / 15 / 1662-0097 \$ 39.50 / 0 \quad \text { Karger }\end{array}$ \\
$\begin{array}{l}\text { E-Mail karger@karger.com } \\
\text { www.karger.com/iaa }\end{array}$ & $\begin{array}{l}\text { This is an Open Access article licensed under the terms of the } \\
\text { Creative Commons Attribution-NonCommercial 3.0 Un- } \\
\text { ported license (CC BY-NC) (www.karger.com/OA-license), } \\
\text { applicable to the online version of the article only. Distribu- } \\
\text { tion permitted for non-commercial purposes only. }\end{array}$
\end{tabular}

Correspondence to: Assoc. Prof. Karin Hoffmann-Sommergruber

Department of Pathophysiology and Allergy Research

Medical University of Vienna, Waehringer Guertel 18-20

AT-1090 Vienna (Austria)

E-Mail karin.hoffmann@meduniwien.ac.at 
and subsequently stimulate the immune response via activation and differentiation of T-helper (Th) cells into their various subtypes $[2,3]$. Allergy is driven by allergenspecific CD4+ Th2 cells, which produce the cytokines IL4, IL-5 and IL-13 [4]. These cytokines play a major role in IgE production by allergen-specific B cells [5].

Allergen uptake and processing by DCs is a pivotal step in the induction of Th2 responses. In vitro, monocyte-derived DCs (MoDCs) have shown upregulation of surface marker expression (e.g. CD80, CD83, CD86, and HLA-DR) after stimulation with lipopolysaccharides (LPS) [6, 7], Bet v 1 [8-10], Pru p 3 [11], and Der p 1 [12]. Furthermore, differentiation of naïve $\mathrm{T}$ cells into Th2 cells, as assessed by $\mathrm{T}$-cell proliferation or the preferential production of Th2 cytokines, were reported in response to Bet v 1 [8], Mal d 1 [9], Pru p 3 [11], Ara h 1 [13], and grass pollen extract [14] with the help of MoDCs. Studies performed with Phl p 5 are less clear, showing attenuated maturation in Langerhans cells [15].

In previous studies we investigated the influence of Bet $\mathrm{v} 1$ isoforms and Bet v 1 homologous food allergens on the polarization of Th cells from patients allergic to birch pollen [9]. In the present study we asked whether the effect seen with Bet $v 1$ in cells derived from birch-pollenallergic patients is comparable to other inhalant allergens (e.g. Phl p 5) in grass-pollen-allergic patients. Therefore, we analysed the impact of purified allergens Bet $\mathrm{v} 1$ and $\mathrm{Phl} \mathrm{p} 5$ in a group of polysensitized patients suffering from inhalant allergies. In parallel, we used Act d 10 as a control allergen. The previously established in vitro model for MoDCs was applied as well as the co-culture experiments with autologous $\mathrm{T}$ cells.

\section{Materials and Methods}

\section{Study Subjects}

Allergic individuals suffering from inhalant allergies (birch pollen, grass pollen and house dust mite) were included in this study. The diagnosis of allergy was based on a characteristic history of clinical symptoms (allergic conjunctivitis, rhinitis, urticaria, and asth$\mathrm{ma}$ ) and on at least one of the following diagnostic criteria: a positive skin prick test or a positive ImmunoCAP. Serum IgE specific for Bet $\mathrm{v} 1$, Phl p 5, Der p 2, and Act d 10 (negative control) was determined by ELISA as previously described [16]. OD values were counted positive if they exceeded the mean OD of the negative controls by more than three standard deviations (data not shown). Based on the sensitization pattern, allergic individuals $(\mathrm{n}=18)$ were classified as follows: a Bet v 1 positive $(B+; n=9)$ and a Bet $v 1$ negative $(B-; n=9)$ group, and in parallel a $\mathrm{Phl} p 5$ positive $(\mathrm{P}+; \mathrm{n}=11)$ and a $\mathrm{Phl} \mathrm{p} 5$ negative $(\mathrm{P}-; \mathrm{n}=7)$ group, respectively. None of the serum samples displayed IgE recognition directed against the control allergen Act d 10. Blood samples from 6 non-allergic healthy donors (NA group) without any allergic symptoms or allergen-specific IgE antibodies were used as a control group (table 1). The characteristics of the patients are summarized in table 1 . The study was authorized by the Ethics Committee of the Medical University of Vienna (ethics committee approval number: 038/2009).

\section{Allergens}

Recombinant Bet v 1.0101 was expressed and purified as previously described [9]. Recombinant Phl p 5 was purchased from Biomay AG (Vienna, Austria). Natural Act d 10 was purified from green kiwifruit as previously described [17]. LPS was obtained from Sigma-Aldrich (Steinheim, Germany). Bacterial endotoxin concentration of the allergen batches as determined by the Limulus Amebocyte Lysate QCL-1000 assay (Cambrex, Walkersville, Md., USA) were below 3 endotoxin units/mg.

\section{Preparation of Cells and Stimulation}

Heparinized blood samples were obtained from donors, and immature MoDCs were generated as previously described [8]. Briefly, monocytes were isolated from purified PBMCs by a Percoll (GE Healthcare, Uppsala, Sweden) gradient (2,100 g, $45 \mathrm{~min})$. After isolation the cells were cultured in Iscove's modified Dulbecco's medium (IMDM; Bio-Whittaker, Walkersville, Md., USA) containing gentamycin ( $86 \mathrm{mg} / \mathrm{l}$; Lactan, Graz, Austria) and $10 \%$ fetal calf serum (FCS; Invitrogen, Carlsbad, Calif., USA) supplemented with GM-CSF $(500 \mathrm{U} / \mathrm{ml})$ and IL-4 $(250 \mathrm{U} / \mathrm{ml}$; both R\&D Systems, Minneapolis, Minn., USA) in 24-well culture plates (Greiner BioONE, Kremsmuenster, Austria). On day 7, maturation of MoDCs was induced by the addition of $25 \mathrm{ng} / \mathrm{ml} \mathrm{TNF- \alpha} \mathrm{(Strathmann}$ $\mathrm{GmbH} \&$ Co. KG, Hamburg, Germany) and $10 \mathrm{ng} / \mathrm{ml}$ IL-1 $\beta$ (PeproTech, Inc., Rocky Hill, N.J., USA) referred to in the text as maturation-inducing factors (MFs) for $48 \mathrm{~h}$. Simultaneously, MoDCs were stimulated with either $10 \mu \mathrm{g} / \mathrm{ml} \mathrm{rBet} \mathrm{v} 1, \mathrm{rPhl}$ p 5 or natural Act d 10. As controls, cells were either treated with $1 \mu \mathrm{g} / \mathrm{ml}$ LPS (Sigma-Aldrich) or MFs or were used without any treatment. After $48 \mathrm{~h}$, supernatants were collected and stored in aliquots at $-20^{\circ} \mathrm{C}$ until cytokine measurement. All subsequent tests were performed after harvesting and extensive washing of the cells to remove allergens, MFs and LPS.

\section{Nä̈ve CD4+ T-Cell Purification}

Peripheral blood lymphocytes were isolated using Percoll density gradient centrifugation (Sigma-Aldrich) as previously described [8]. Naïve CD4+CD45RA+ cells were isolated by negative selection using the naïve CD4+ T-Cell isolation Kit II (Miltenyi Biotech, Bergisch-Gladbach, Germany). Briefly, total CD4+ T-cell population was depleted of non-Th cells and memory CD4+ T cells via magnetic beads loaded with biotin-conjugated monoclonal antibodies. Afterwards, T cells were frozen in IMDM containing 50\% (v/v) FCS (Invitrogen) and 10\% (v/v) dimethyl sulfoxide (Merck KGaA, Germany) for 7 days until use (survival rate after thawing: 60-80\%).

\section{Flow Cytometry}

MoDCs stimulated for $48 \mathrm{~h}$ were harvested, washed and suspended in FACS buffer consisting of PBS, 1\% BSA, 0.1\% sodium azide, $2 \%$ FCS (GIBCO; Invitrogen), and 1\% human serum (Lonza, Basel, Switzerland). The cells were washed twice and incubated for $45 \mathrm{~min}$ at $4^{\circ} \mathrm{C}$ with saturating concentrations of FITC-conjugated anti-CD80 or phycoerythrin-conjugated anti-CD83, anti-CD86 and anti-OX40L, allophycocyanin-conjugated anti-HLA-DR and
98

Int Arch Allergy Immunol 2015;166:97-106 DOI: $10.1159 / 000375405$
Ashjaei et al. 
Table 1. Characteristics of subjects

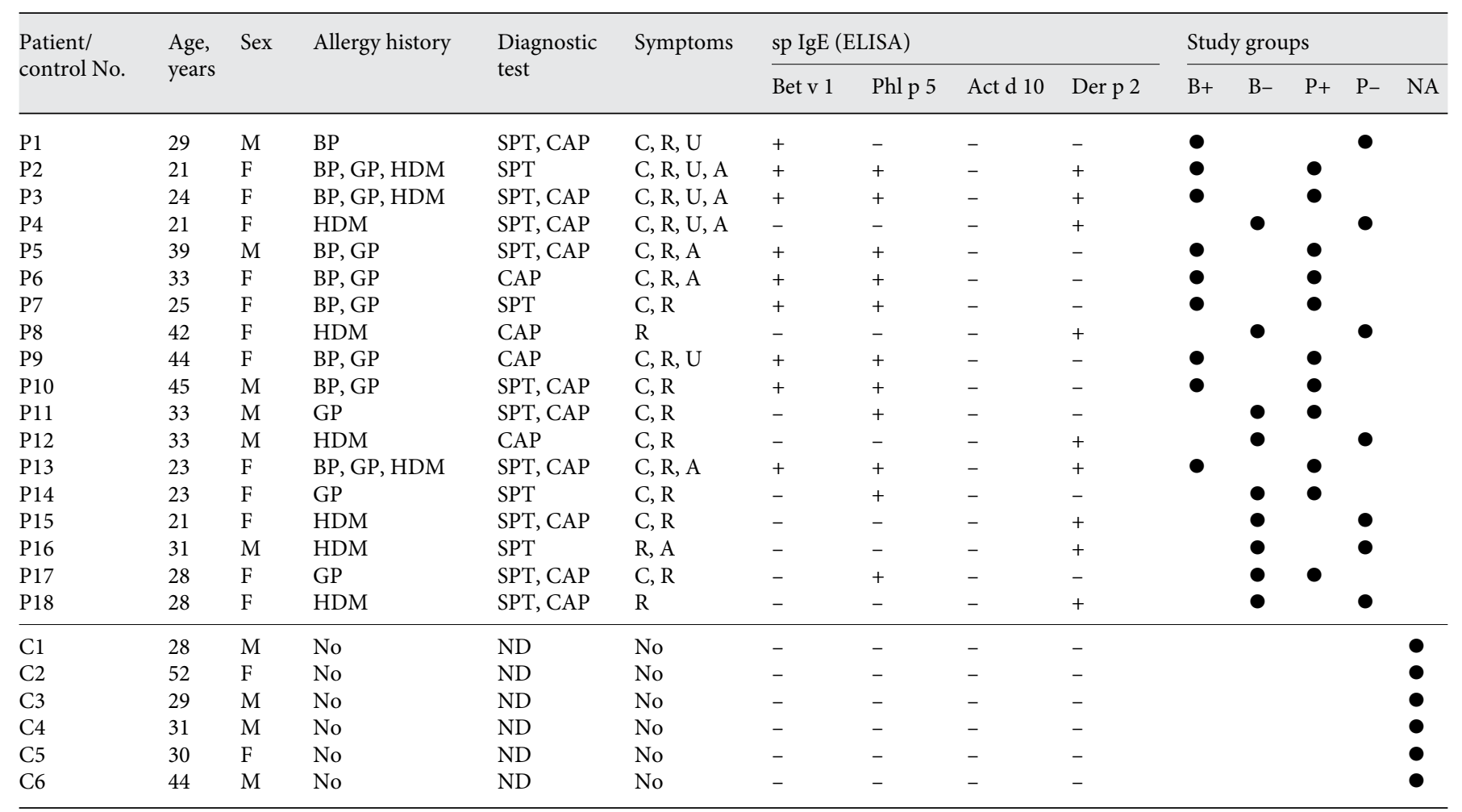

$\mathrm{P}=$ Patient $\mathrm{C}=$ control; $\mathrm{A}=$ asthma; $\mathrm{BP}=$ birch pollen; $\mathrm{C}=$ conjunctivitis; $\mathrm{GP}=$ grass pollen; $\mathrm{HDM}=$ house dust mite; $\mathrm{R}=$ rhinitis; $\mathrm{U}=$ urticaria; $\mathrm{SPT}=$ skin prick test; $\mathrm{CAP}=$ ImmunoCAP; sp IgE = allergen-specific IgE tested by ELISA; ND = not determined (below the detection limit).

anti-CD11c antibodies (all from BD Biosciences, San Jose, Calif., USA) or FITC-conjugated anti-Jagged 1 antibody (R\&D Systems). Fluorescence was measured on a FACS Canto flow cytometer (BD Biosciences), and 10,000 events were acquired and analysed using the BD FACS Diva software.

\section{Proliferation Assay}

Stimulated MoDCs $\left(1 \times 10^{4}\right.$ cells $)$ and autologous naïve T cells $\left(1 \times 10^{5}\right.$ cells $)$ were co-cultured in IMDM supplemented with $86 \mu \mathrm{g} / \mathrm{l}$ gentamycin (Lactan) and 10\% (v/v) FCS in 96-well plates (Corning Life Sciences, Lowell, Mass., USA) in triplicate at $37^{\circ} \mathrm{C}$ and $5 \% \mathrm{CO}_{2}$. After 5 days, supernatants were collected and stored in aliquots at $-20^{\circ} \mathrm{C}$ until the determination of cytokine levels. Subsequently, $1.85 \times 10^{10} \mathrm{~s}^{-1}{ }^{3} \mathrm{H}$-thymidine (GE Healthcare) was added to the wells for $16 \mathrm{~h}$. The cells were harvested and counted in a scintillation $\beta$-counter (MicroBeta Trilux; PerkinElmer, Waltham, Mass., USA). Results were reported as stimulation indices calculated as a ration between the counts per minute of stimulated and unstimulated cells.

\section{Cytokine Assays}

The concentrations of human IL-5, IL-10, IL-12(p70), IL-13, and INF- $\gamma$ in culture supernatants were determined by ELISA according to the instructions from the distributor of the used pairs of antibodies (Thermo Scientific, Rockford, Ill., USA). OD values were measured by the Spectra Max system (Molecular Devices, Sunny- vale, Calif., USA) according to the manufacturer's instructions, and the detection limits were as follows: IL-5: $1.0 \mathrm{pg} / \mathrm{ml}$, IL-10: $2.2 \mathrm{pg} /$ $\mathrm{ml}$; IL-12p70: $0.5 \mathrm{pg} / \mathrm{ml}$; IL-13: $21.0 \mathrm{pg} / \mathrm{ml}$, and INF- $\gamma: 11.4 \mathrm{pg} / \mathrm{ml}$.

\section{Statistics}

The allergen-induced changes in proliferation and cytokine levels were analysed using the Wilcoxon signed-rank test. $\mathrm{p}$ values $<0.05$ were considered statistically significant.

\section{Results}

\section{Maturation of MoDCs Upon Allergen Stimulation} and Maturation Factors

After 7 days of culture, generated MoDCs were analysed for the expression of CD11c and CD14. Results showed that the cells displayed a high expression level of CD11c (91-98\%, mean $95 \pm 3.6)$ and were negative for CD14, indicating specificity for immature DCs (online suppl. fig. S1; for all online suppl. material, see www. karger.com/doi/10.1159/000375405). Subsequently, costimulatory molecule expression of MoDCs was analysed upon stimulation with Bet v 1 and Phl p 5. Our experi- 
Fig. 1. Surface marker expression of MoDCs from patients diagnosed with inhalant allergies (birch pollen, grass pollen and house dust mite; $\mathrm{n}=18$; all samples were grouped into Bet v 1+ or Bet v 1groups and in parallel into $\mathrm{Phl} p 5+$ and $\mathrm{Phl}$ p 5-, respectively). MFI = Mean fluorescence intensity. MoDCs were stimulated for $48 \mathrm{~h}$ with either MFs alone or together with either Bet $\mathrm{v} 1$ or Phl p 5 or LPS (48 h), or kept untreated as control (-). The stimulated MoDCs were stained with fluorochrome-labelled antibodies specific for CD80, CD83, CD86, HLA-DR, Jagged-1, and OX40L analysed by flow cytometry. Data are expressed as box plot summary of the mean fluorescence intensity.
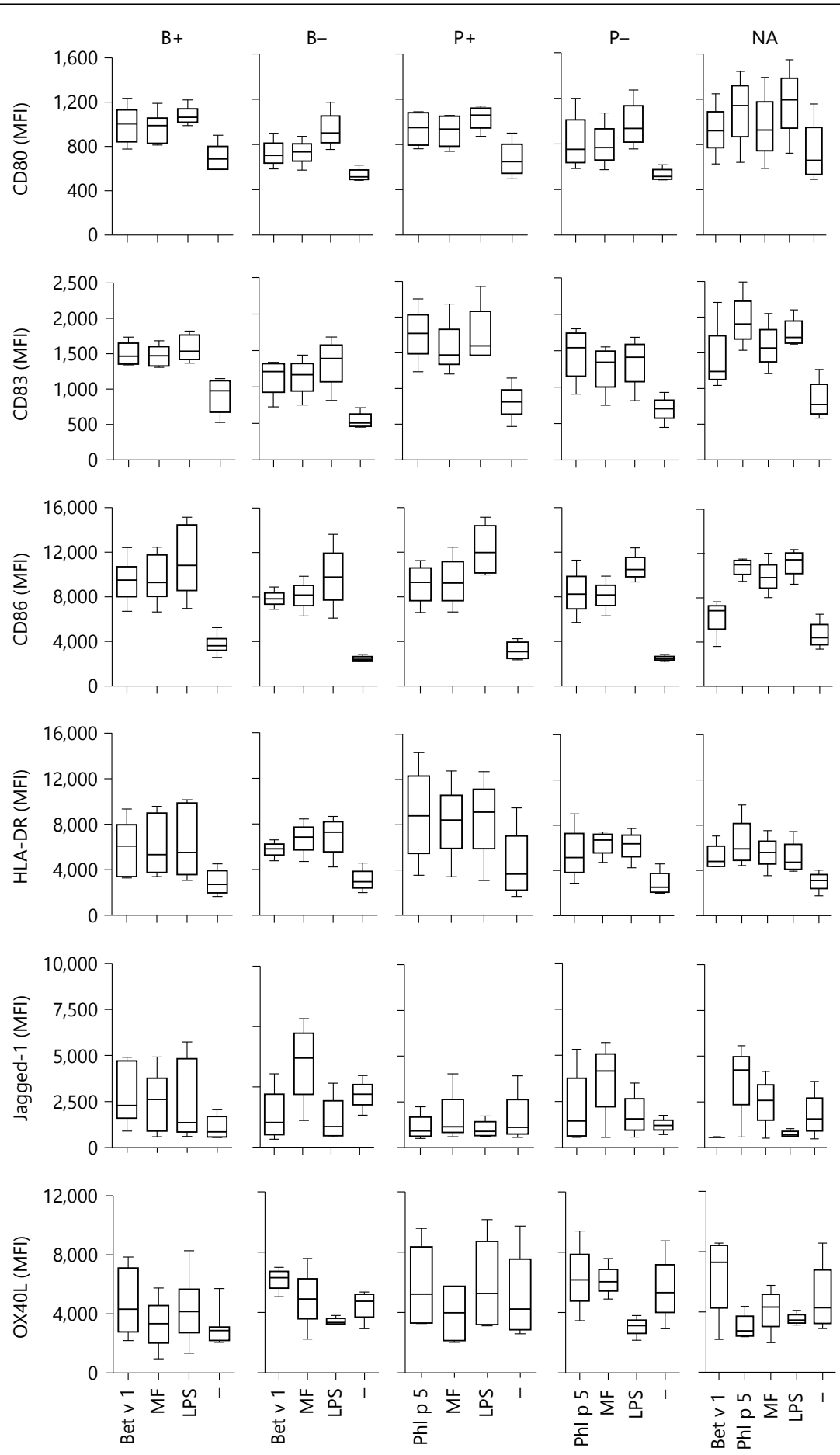

ments demonstrated that exposure of MoDCs to MFs alone induced an upregulation of the co-stimulatory molecules CD80 and CD86 and maturation markers CD83 and HLA-DR, thus verifying the mature status of the MoDCs (fig. 1) compared to untreated cells. The ad- dition of either Bet $\mathrm{v} 1$ or Phl $\mathrm{p} 5$ did not further increase the expression of these surface markers in all 4 allergic study groups and non-atopic controls (fig. 1). Also, cells stimulated with LPS showed an upregulation of costimulatory molecules (fig. 1). In parallel, the expression of Jag- 
Fig. 2. Proliferation of autologous naïve $\mathrm{T}$ cells from grass and birch pollen allergic patients after activation with autologous MoDCs pulsed with Bet v 1, Phl p 5, MFs, and LPS. SI $=$ Stimulation indices. After 5 days of co-culture, proliferation was assessed by ${ }^{3} \mathrm{H}$-thymidine incorporation. The results are shown as stimulation indices. Statistical significance was determined by the Wilcoxon signed-rank test. ${ }^{*} \mathrm{p}<$ $0.05,{ }^{* *} \mathrm{p}<0.01$.

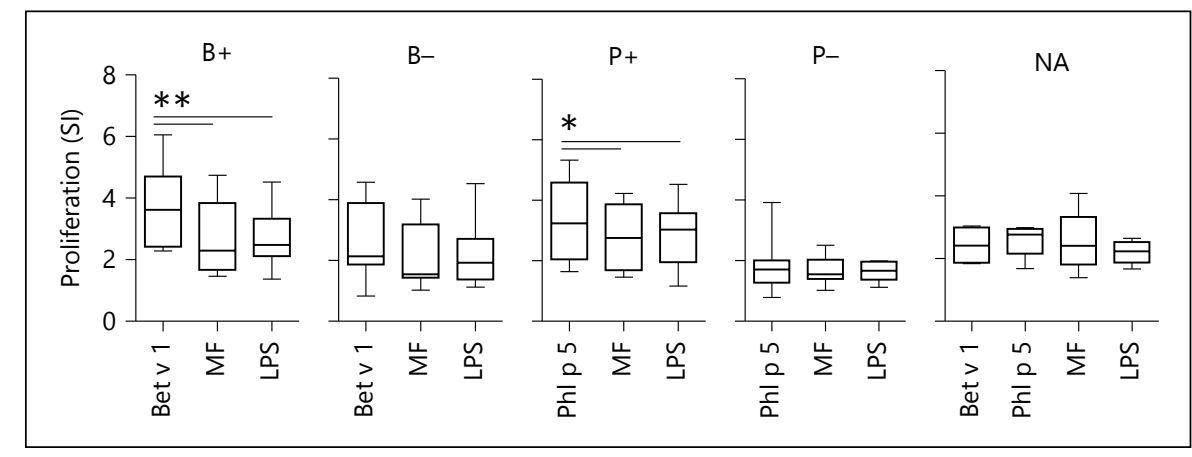

Supernatants from co-culture of MoDCs and autologous naïve T cells were analysed for IL-5, IL-10, IL-13, and IFN- $\gamma$ levels (fig. 3b). IL-5 and IL-13 levels were significantly increased in the $\mathrm{B}+$ group upon stimulation with Bet $\mathrm{v} 1$ (fig. 3b). The addition of $\mathrm{Phl} \mathrm{p} 5$ induced the upregulation of IL-5 $(\mathrm{p}=0.06)$ and IL-13 $(\mathrm{p}<0.05)$ in the $\mathrm{P}+$ group (fig. $3 \mathrm{~b}$ ). This effect was not observed in response to the allergens in the $\mathrm{B}-$ or $\mathrm{P}$ - group, nor was it observed in the NA group. The addition of Bet $\mathrm{v} 1$ and $\mathrm{Phl}$ p 5, respectively, did not affect the levels of IL-10 and INF- $\gamma$ in any of the allergic groups (fig. 3b).

\section{Control Experiments with Act d 10}

To evaluate the effect of Act $d 10$ (the non-specific lipid transfer protein from kiwifruit) - an allergen with no specificity for all allergic groups - control experiments were performed in parallel.

The addition of Act d 10 to matured MoDCs derived from all study groups did not change surface marker expression levels of CD80, CD83, CD86, HLA-DR, Jagged-1, and OX40L compared to Bet v 1, Phl p 5 and MFs. As an example, CD86 analyses for the $\mathrm{B}+, \mathrm{P}+$ and NA groups are shown in figure $4 \mathrm{a}$.

MoDCs pulsed with Act d 10 were unable to induce higher levels of T-cell proliferation or Th2-type cytokines (IL-5, IL-13) compared to MFs (fig. 4b). Furthermore, this effect was significantly lower compared to Bet $\mathrm{v} 1$ and $\mathrm{Phl} \mathrm{p} 5$ in the respective study groups.

\section{Discussion}

Among all known proteins, only a minority have been identified as allergens inducing a Th2-type immune response in genetically predisposed individuals. However, the underlying mechanisms and shared physicochemical features of the causative proteins are still unknown. In the recent past it became evident that the interaction of aller- 
Fig. 3. Detection of cytokine production by stimulated MoDCs and naïve Th cells after stimulation with allergens (Bet v 1, Phl p 5). a Supernatants of MoDCs were assayed by ELISA for the cytokines IL-12 (the active form IL-12p70 was analysed) and IL-10. b Supernatants of co-cultures of stimulated MoDCs with naïve $T$ cells were tested for IL-5, IL-13, IL-10, and INF- $\gamma$ levels. Statistical significance was determined by the Wilcoxon signed-rank test. ${ }^{*} \mathrm{p}<0.05$.

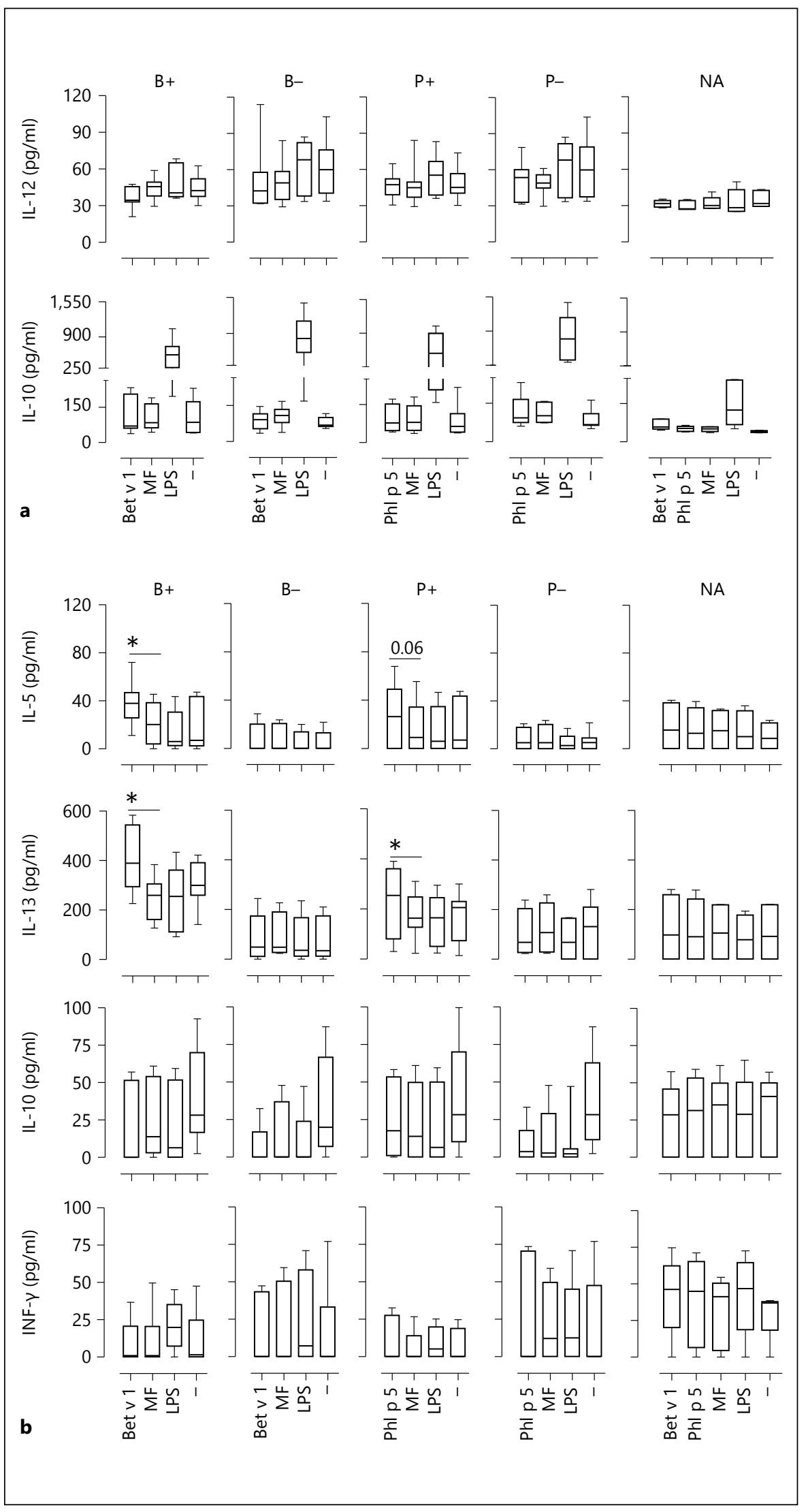


Fig. 4. Effect of MoDCs pulsed with Act d 10 on the autologous T-cell activation from patients with inhalant allergies. MFI = Mean fluorescence intensity; SI = stimulation indices. a Upon addition of an unspecific allergen (kiwifruit allergen: Act d 10), the expression of surface markers from MoDCs were analysed. CD86 is presented as a representative marker. b MoDC-dependent autologous $\mathrm{T}$-cell proliferation pulsed with Act d 10 was investigated and shown as stimulation indices. In addition, Th2-type cytokine levels were assessed. Statistical significance was determined by the Wilcoxon signed-rank test. ${ }^{*} \mathrm{p}<0.05$.

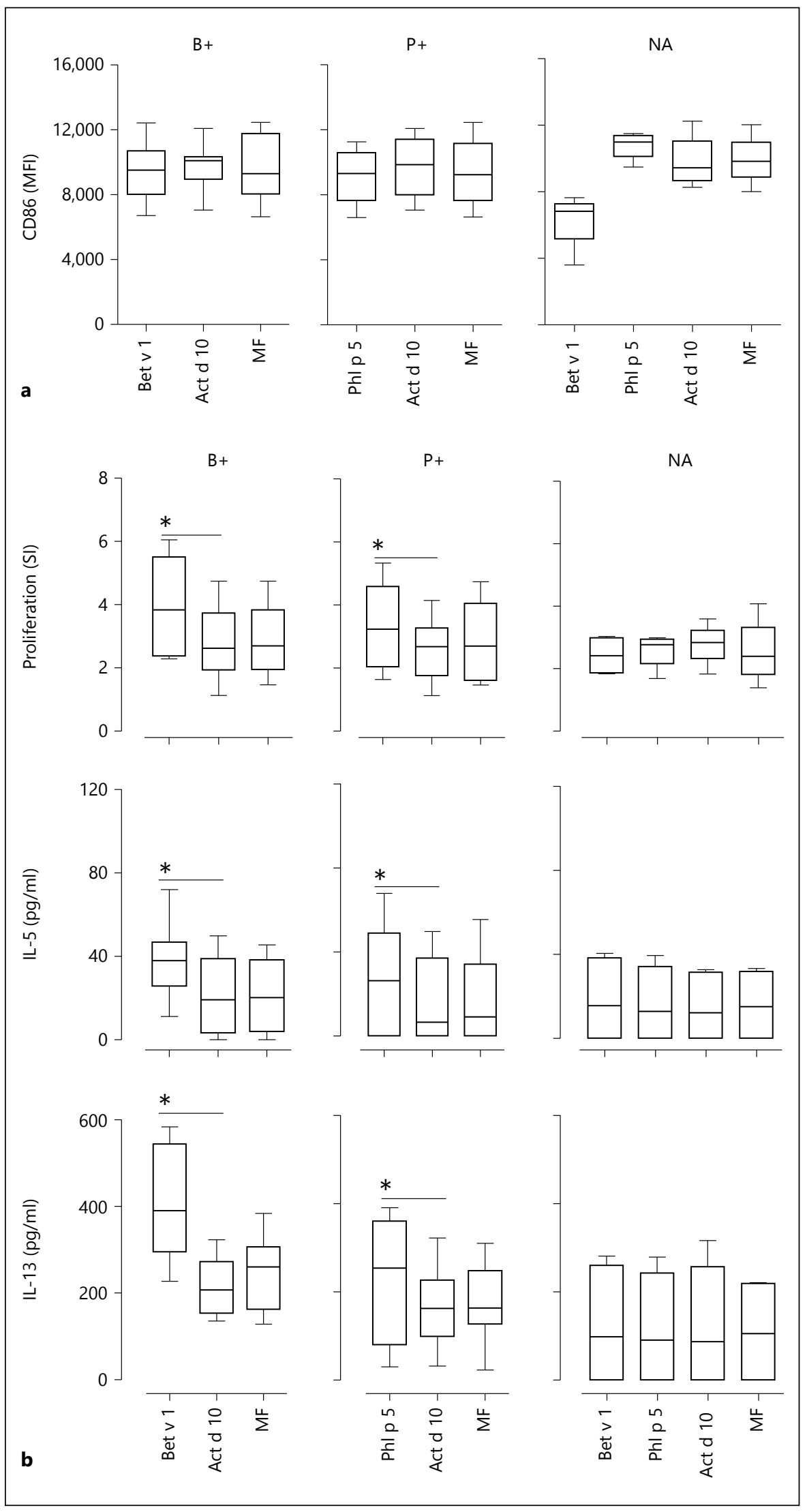


gens with the innate immune system seems to be crucial for inducing an allergic response [18]. However, it is still unknown whether the polysensitized status of the allergic patient impacts on the immune response to individual allergens without discriminating between the individual allergens or whether different responses are mounted. Therefore, the current study included a patient population that is polysensitized, which is normally seen in daily practice in an allergy clinic.

DCs are specialized for the uptake, processing and presentation of antigens to T cells $[19,20]$. Upon activation, DCs undergo a process of maturation and become efficient in presenting antigens to $\mathrm{T}$ lymphocytes. A variety of danger signals can lead to the activation and maturation of DCs, including pathogen components like LPS, cytokines released during inflammation such as TNF-a and IL-1 and T-cell ligands like CD40L [19, 21-24]. For example, Der $\mathrm{p} 2$, a house dust mite allergen, activates the MyD88 and TRIF inflammatory pathways by binding to TLR4 and LPS. In a recent study by Deifl et al. [25], the MoDC uptake of Bet v 1 was enhanced when LPS was added. Other studies have provided evidence that allergens such as Bet v 1, Fel d 1 and group 1 grass pollen allergens and their binding activity to lipids may mimic pathogen-associated molecular patterns and thus facilitate cellular uptake [18]. Similarly, glycosylated allergens such as Der f 1 , Fel d 1 and Ole e 1 can be readily taken up via the mannose receptor [18].

However, for full activation of $\mathrm{T}$ cells additional signals are required. So far, a range of costimulatory signals has been identified and their significance as important regulators of immune pathological processes has been elucidated. Members of the B7 and TNF superfamilies interacting with members of the CD28 and TNF-R superfamilies play an important role in costimulatory processes [26]. The ICOS-L-ICOS signalling pathway promotes Th cell differentiation and B-cell response [26]. There is increasing evidence from mouse experiments that ICOS signalling is crucial during the effector phase of an already established allergic immune response [27]. In contrast, the PD-L1-PD-1 system is regarded as a negative regulator by inhibiting T-cell proliferation and cytokine production [26]. In murine models the blocking of PD-1 and PD-L1 lead to increased allergic responses, suggesting that $\mathrm{PD}-\mathrm{L} 1$ provides an inhibitory role during the sensitization phase [27], whereas PD-L2 signalling seems to contribute to asthma exacerbation [28]. Taken together, studying the function of costimulatory molecules in both the allergic sensitization and effector phases may help to develop new therapeutic intervention strategies.
Previous studies have shown a significant increase in CD86 expression in immature DCs in response to Der $\mathrm{p} 1$, a major house dust mite allergen [12], and Pru p 3, the nonspecific lipid transfer protein from peach [11], in the allergic individuals. This is in contrast to our observation, where we did not see an increase of both CD86 and CD80 upon addition of Bet $\mathrm{v} 1$ and Phl $\mathrm{p} 5$ in the respective sensitized patients. Hammad et al. [12] showed that Der $p 1$ induced the upregulation of CD86 in DCs from patients allergic to house dust mite at a dose of $100 \mathrm{ng} / \mathrm{ml}$, while this was not the case for CD80. In contrast to the protocol used by Hammad et al., we applied the individual allergens together with maturation factors (IL- $1 \beta$, TNF- $\alpha$ ). Comparing the addition of MFs alone versus MFs and allergen did not significantly differ in the upregulation of both CD86 and CD80, respectively. However, upregulation was observed in both cases. Also, the intrinsic properties of the allergen could have contributed to the differential upregulation of costimulatory molecules. For example, it is known that the mannose receptor is involved in the Der $\mathrm{p} 1$ uptake of DCs, which is not the case for Bet v 1 and Phl p 5.

In summary, we think that the upregulation of costimulatory molecules - a very important event for the interaction of DCs with T cells - is dependent on various factors such as the amount of allergen/antigen administered, the nature of the allergen/antigen and the individual cytokine environment.

Cytokine production by DCs such as IL-10 and IL-12 drives the type of T-cell response $[3,13,29]$. IL-12p70 under the control of TLR8 and TLR4 plays a crucial role in polarizing $\mathrm{T}$ cells to an IFN- $\gamma$-producing Th1 phenotype $[30,31]$, while IL-4 induces Th2 differentiation [32, 33]. It has been proposed that stimuli that fail to induce IL-12 expression in DCs programme them to induce Th2 responses, as shown for allergic rhinitis $[34,35]$. This reduced IL-12 production by DCs might be regulated by IL-10 or TNF- $\alpha$ [36]. Furthermore, common allergen sources such as house dust mite and peanut extract inhibited DC IL-12 production similarly to thymic stromal lymphopoietin, resulting in the induction of a Th2 response [37]. Accordingly, we found no induction of IL12 p70 and IL- 10 by DCs stimulated with either Bet $\mathrm{v} 1$ or Phl p 5, although it has to be noted that there is substantial variability in IL-12p70 production between individuals [38], and up to $30 \%$ of donors fail to secrete IL-12p70 in response to LPS [39-41]. Interestingly, low levels of IL12 p70 were also found in our control group, even upon stimulation with LPS.

The ability of human DCs to endocytose, process and present antigens is tightly related to their functional state. 
In addition, human DCs constitute a heterogeneous population. Therefore, the establishment/generation of a highly functional in vitro cell system mimicking the in vivo situation is needed when studying the antigen-presenting T-cell interaction. In some studies myeloid DCs, blood CD11c+ DCs and in vitro MoDCs were investigated for their surface marker expression, endocytotic activity and T-cell polarization $[42,43]$. While expression levels of HLA-DR, CD40, CD86, and CD83 were comparable between freshly isolated blood CD11c+ DCs and MoDCs, the endocytotic activity was much higher in blood DCs than in MoDCs [43]. In addition, T-cell proliferation was higher upon stimulation by blood CD11c+ and pointed towards Th1 polarization. These functional differences in the individual DC subsets suggest that careful handling of this cellular system is mandatory to obtain reliable data.

In summary, we could show that, similarly to Bet $\mathrm{v} 1$, $\mathrm{Phl} \mathrm{p} 5$ is capable of inducing a Th2-type polarization via autologous DCs in sensitized patients. However, the underlying mechanisms of the tight interplay between DCs and $\mathrm{T}$ cells and their role in the allergic responses are still unknown. Although crucial components such as LPS contamination and glycan moieties could be ruled out, it remains to be investigated whether and how the innate immune response is involved in mounting an allergic response and whether via activation of this pathway certain immune response control points are to be identified that decide upon developing an allergic response versus developing a tolerizing status [18]. In this context further studies are needed to investigate the imbalance and downregulation of regulatory cytokines and the role of costimulatory molecules. These studies should apply single, purified allergens to assess the individual allergenic capacity of these molecules. This in turn will not only contribute to a better understanding of the onset of the allergic immune response but also identify new promising targets for treatment strategies of allergic diseases.

\section{Acknowledgement}

This work was funded by the Austrian Science Fund (FWF) projects SB F4603 (K.H.-S.) and SB F4608 (H.B.).

\section{Disclosure Statement}

The authors declare no conflicts of interest.

\section{References}

1 Asher MI, Montefort S, Bjorksten B, Lai CK, Strachan DP, Weiland SK, Williams $\mathrm{H}$ : Worldwide time trends in the prevalence of symptoms of asthma, allergic rhinoconjunctivitis, and eczema in childhood: ISAAC phases one and three repeat multicountry cross-sectional surveys. Lancet 2006;368:733-743.

2 Bettelli E, Korn T, Oukka M, Kuchroo VK: Induction and effector functions of TH17 cells. Nature 2008;453:1051-1057.

3 Zhu J, Yamane H, Paul WE: Differentiation of effector CD4 T cell populations. Annu Rev Immunol 2010;28:445-489.

4 Hammad $\mathrm{H}$, Plantinga M, Deswarte K, Pouliot P, Willart MA, Kool M, Muskens F, Lambrecht BN: Inflammatory dendritic cells - not basophils - are necessary and sufficient for induction of Th2 immunity to inhaled house dust mite allergen. J Exp Med 2010;207:20972111.

5 Wills-Karp M, Finkelman FD: Untangling the complex web of IL-4- and IL-13-mediated signaling pathways. Sci Signal 2008;1:pe55.

6 Hellman P, Eriksson H: Early activation markers of human peripheral dendritic cells. Hum Immunol 2007;68:324-333.

7 Okamoto M, Takeda K, Lucas JJ, Joetham A, Yasutomo K, Gelfand EW: Low-dose lipopolysaccharide affects lung allergic responses by regulating Jagged 1 expression on antigenpulsed dendritic cells. Int Arch Allergy Immunol 2012;157:65-72.

8 Smole U, Balazs N, Hoffmann-Sommergruber K, Radauer C, Hafner C, Wallner M, Ferreira F, Grossinger R, de Jong EC, Wagner S, Breiteneder H: Differential T-cell responses and allergen uptake after exposure of dendritic cells to the birch pollen allergens Bet $\mathrm{v}$ 1.0101, Bet v 1.0401 and Bet v 1.1001. Immunobiology 2009;215:903-909.

9 Smole U, Wagner S, Balazs N, Radauer C, Bublin M, Allmaier G, Hoffmann-Sommergruber $\mathrm{K}$, Breiteneder $\mathrm{H}$ : Bet $\mathrm{v} 1$ and its homologous food allergen Api g 1 stimulate dendritic cells from birch pollen-allergic individuals to induce different Th-cell polarization. Allergy 2010;65:1388-1396.

10 Kitzmuller C, Wallner M, Deifl S, Mutschlechner S, Walterskirchen C, Zlabinger GJ, Ferreira F, Bohle B: A hypoallergenic variant of the major birch pollen allergen shows distinct characteristics in antigen processing and T-cell activation. Allergy 2012; 67:1375-1382.

11 Gomez E, Diaz-Perales A, Tordesillas L, Dona I, Torres MJ, Blazquez AB, Gomez F, Blanca M, Mayorga C: Effect of Pru p 3 on dendritic cell maturation and T-lymphocyte prolifera- tion in peach allergic patients. Ann Allergy Asthma Immunol 2012;109:52-58.

12 Hammad H, Charbonnier AS, Duez C, Jacquet A, Stewart GA, Tonnel AB, Pestel J: Th2 polarization by Der p 1-pulsed monocytederived dendritic cells is due to the allergic status of the donors. Blood 2001;98:11351141.

13 Ruiter B, Shreffler WG: The role of dendritic cells in food allergy. J Allergy Clin Immunol 2012;129:921-928.

14 Lundberg K, Lindstedt M, Larsson K, Dexlin L, Wingren C, Ohlin M, Greiff L, Borrebaeck CA: Augmented Phl p 5-specific Th2 response after exposure of dendritic cells to allergen in complex with specific IgE compared to IgG1 and IgG4. Clin Immunol 2008;128: 358-365.

15 Allam JP, Wurtzen PA, Reinartz M, Winter J, Vrtala S, Chen KW, Valenta R, Wenghoefer M, Appel T, Gros E, Niederhagen B, Bieber T, Lund K, Novak N: Phl p 5 resorption in human oral mucosa leads to dose-dependent and time-dependent allergen binding by oral mucosal Langerhans cells, attenuates their maturation, and enhances their migratory and TGF- $\beta 1$ and IL-10-producing properties. J Allergy Clin Immunol 2010;126:638645.e1. 
16 Suzuki M, Zheng X, Zhang X, Zhang ZX, Ichim TE, Sun H, Nakamura Y, Inagaki A, Beduhn M, Shunnar A, Garcia B, Min WP: A novel allergen-specific therapy for allergy using CD40-silenced dendritic cells. J Allergy Clin Immunol 2010;125:737-743.

17 Le TM, Bublin M, Breiteneder H, FernandezRivas M, Asero R, Ballmer-Weber B, Barreales L, Bures P, Belohlavkova S, de Blay F, Clausen M, Dubakiene R, Gislason D, van Hoffen E, Jedrzejczak-Czechowicz M, Kowalski ML, Kralimarkova T, Lidholm J, DeWitt AM, Mills CE, Papadopoulos NG, Popov T, Purohit A, van Ree R, Seneviratne S, Sinaniotis A, Summers C, Vazquez-Cortes S, Vieths S, Vogel L, Hoffmann-Sommergruber K, Knulst AC: Kiwifruit allergy across Europe: clinical manifestation and $\operatorname{IgE}$ recognition patterns to kiwifruit allergens. J Allergy Clin Immunol 2013;131:164-171.

18 Thomas WR: Innate affairs of allergens. Clin Exp Allergy 2013;43:152-163.

19 Banchereau J, Briere F, Caux C, Davoust J, Lebecque S, Liu YJ, Pulendran B, Palucka K: Immunobiology of dendritic cells. Annu Rev Immunol 2000;18:767-811.

20 Foti M, Granucci F, Pelizzola M, Beretta O, Ricciardi-Castagnoli P: Dendritic cells in pathogen recognition and induction of immune responses: a functional genomics approach. J Leukoc Biol 2006;79:913-916.

21 Brunner C, Seiderer J, Schlamp A, Bidlingmaier M, Eigler A, Haimerl W, Lehr HA, Krieg AM, Hartmann G, Endres S: Enhanced dendritic cell maturation by TNF- $a$ or cytidinephosphate-guanosine DNA drives T cell activation in vitro and therapeutic anti-tumor immune responses in vivo. J Immunol 2000; 165:6278-6286.

22 Ding X, Yang W, Shi X, Du P, Su L, Qin Z, Chen J, Deng H: TNF receptor 1 mediates dendritic cell maturation and CD8 T cell response through two distinct mechanisms. J Immunol 2011;187:1184-1191.

23 Flores-Romo L: In vivo maturation and migration of dendritic cells. Immunology 2001; 102:255-262.

24 Ritter U, Meissner A, Ott J, Korner H: Analysis of the maturation process of dendritic cells deficient for TNF and lymphotoxin- $\alpha$ reveals an essential role for TNF. J Leukoc Biol 2003; 74:216-222.
25 Deifl S, Kitzmuller C, Steinberger P, Himly M, Jahn-Schmid B, Fischer GF, Zlabinger GJ, Bohle B: Differential activation of dendritic cells by toll-like receptors causes diverse differentiation of naive CD4+ T cells from allergic patients. Allergy 2014;69:1602-1609.

26 Leitner J, Grabmeier-Pfistershammer K, Steinberger P: Receptors and ligands implicated in human $\mathrm{T}$ cell costimulatory processes. Immunol Lett 2010;128:89-97.

27 Kallinich T, Beier KC, Gelfand EW, Kroczek RA, Hamelmann E: Co-stimulatory molecules as potential targets for therapeutic intervention in allergic airway disease. Clin Exp Allergy 2005;35:1521-1534.

28 Lewkowich IP, Lajoie S, Stoffers SL, Suzuki Y, Richgels PK, Dienger K, Sproles AA, Yagita H, Hamid Q, Wills-Karp M: PD-L2 modulates asthma severity by directly decreasing dendritic cell IL-12 production. Mucosal Immunol 2013;6:728-739.

29 Pulendran B, Tang H, Manicassamy S: Programming dendritic cells to induce $\mathrm{TH} 2$ and tolerogenic responses. Nat Immunol 2010;11: 647-655.

30 Hsieh CS, Macatonia SE, Tripp CS, Wolf SF, O'Garra A, Murphy KM: Development of TH1 CD4+ T cells through IL-12 produced by Listeria-induced macrophages. Science 1993; 260:547-549.

31 Macatonia SE, Hosken NA, Litton M, Vieira $\mathrm{P}$, Hsieh CS, Culpepper JA, Wysocka M, Trinchieri G, Murphy KM, O’Garra A: Dendritic cells produce IL-12 and direct the development of Th1 cells from naive CD4+ T cells. J Immunol 1995;154:5071-5079.

32 Amsen D, Blander JM, Lee GR, Tanigaki K, Honjo T, Flavell RA: Instruction of distinct CD4 T helper cell fates by different notch ligands on antigen-presenting cells. Cell 2004; 117:515-526.

33 Liotta F, Frosali F, Querci V, Mantei A, Fili L, Maggi L, Mazzinghi B, Angeli R, Ronconi E, Santarlasci V, Biagioli T, Lasagni L, Ballerini C, Parronchi P, Scheffold A, Cosmi L, Maggi E, Romagnani S, Annunziato F: Human immature myeloid dendritic cells trigger a TH2polarizing program via Jagged-1/Notch interaction. J Allergy Clin Immunol 2008;121: 1000-1005.e8.

34 Bilenki L, Gao X, Wang S, Yang J, Fan Y, Han X, Qiu H, Yang X: Dendritic cells from mycobacteria-infected mice inhibits established allergic airway inflammatory responses to ragweed via IL-10- and IL-12-secreting mechanisms. J Immunol 2010;184:7288-7296.
35 Pilette C, Jacobson MR, Ratajczak C, Detry B, Banfield G, VanSnick J, Durham SR, NouriAria KT: Aberrant dendritic cell function conditions Th2-cell polarization in allergic rhinitis. Allergy 2013;68:312-321.

36 Ma X, Sun J, Papasavvas E, Riemann H, Robertson S, Marshall J, Bailer RT, Moore A, Donnelly RP, Trinchieri G, Montaner LJ: Inhibition of IL-12 production in human monocyte-derived macrophages by TNF. J Immunol 2000;164:1722-1729.

37 Chu DK, Llop-Guevara A, Walker TD, Flader K, Goncharova S, Boudreau JE, Moore CL, Seunghyun In T, Waserman S, Coyle AJ, Kolbeck R, Humbles AA, Jordana M: IL-33, but not thymic stromal lymphopoietin or IL-25, is central to mite and peanut allergic sensitization. J Allergy Clin Immunol 2012;131:187200.e1-e8.

38 Muller-Berghaus J, Kern K, Paschen A, Nguyen XD, Kluter H, Morahan G, Schadendorf D: Deficient IL-12p70 secretion by dendritic cells based on IL12B promoter genotype. Genes Immun 2004;5:431-434.

39 Fokkema SJ, Loos BG, Slegte C, van der Velden U: A type 2 response in lipopolysaccharide (LPS)-stimulated whole blood cell cultures from periodontitis patients. Clin Exp Immunol 2002;127:374-378.

40 Peng JC, Abu Bakar S, Richardson MM, Jonsson JJ, Frazer IH, Nielsen LK, Morahan G, Thomas R: IL10 and IL12B polymorphisms each influence IL-12p70 secretion by dendritic cells in response to LPS. Immunol Cell Biol 2006; $84: 227-232$.

41 Amoudruz P, Holmlund U, SaghafianHedengren S, Nilsson C, SverremarkEkstrom E: Impaired Toll-like receptor 2 signalling in monocytes from 5-year-old allergic children. Clin Exp Immunol 2009;155:387394.

42 Osugi Y, Vuckovic S, Hart DN: Myeloid blood CD11c+ dendritic cells and monocyte-derived dendritic cells differ in their ability to stimulate T lymphocytes. Blood 2002;100: 2858-2866.

43 Andersson LI, Cirkic E, Hellman P, Eriksson $\mathrm{H}$ : Myeloid blood dendritic cells and monocyte-derived dendritic cells differ in their endocytosing capability. Hum Immunol 2012; 73:1073-1081. 